on nylon and other polyamide fibres the desirable attributes of the established disperse dyes-good levelling, good coverage of irregular-dyeing yarns, good compatibility in admixture, good temperaturerange properties and good penetration. They are applied in a similar manner. The essential difference is that the 'Procinyl' dyes are applied initially under slightly acid instead of neutral conditions, and that dyeing is completed by an alkaline fixation stage during which certain reactive groups in the 'Procinyl' dye molecules react chemically and irreversibly with the amine or amide groups in the polyamide fibre and so produce dyeings of high wet-fastness. All forms of nylon and other polyamide fibres, of both the staple fibre and continuous-filament types and including woven piece goods, knitted piece goods and hosiery, can be dyed satisfactorily with the new dyes, which may be applied, as necessary, on the jig (covered jigs for preference), on winches, in paddle dyeing machines and in circulating-liquor machines. The initial four 'Procinyl' dyes-a yellow, an orange, a scarlet and a blue-permit an extensive range of shades to be produced because of the wide intercompatibility of the new dyes.

Only slight or negligible reaction takes place between 'Procinyl' dyes and acetate and triacetate rayons, for which the new dyes are not expected to be of much immediate interest, although the wetfastness achieved is generally better than with normal disperse dyes. With the exception of 'Procinyl Yellow G', the dyes are of minor importance on 'Terylene' and other polyester fibres. On 'Acrilan' polyacrylonitrile fibre, although 'Procinyl' dyes build up well to give heavy shades of very high wet-fastness, which results from the reaction between the dye and the basic groups in the fibre, only the yellow is of particular interest, the remaining dyes giving shades of low light fastness. On acrylic fibres not modified by the incorporation of basic substances they display only limited build-up.

\section{British Ceramic Research Association :}

Mellor Library

THe new library of the British Ceramic Research Association-- the Mellor Library-was opened at Stoke-on-Trent on June 16 by Mr. Frank West, vicepresident of the Association and a lifelong friend of the late Dr. J. W. Mellor, in whose honour the library has been named. Dr. Mellor, the well-known physical chemist, turned his mind to problems of the ceramic industry ; Wedgwood, a century and a half previously, had transformed a craft into an industry; Mellor, during the first three decades of the present century, did outstanding service to that industry by giving it the basis of science that had hitherto been largely wanting. As head of the Pottery Department of the North Staffordshire Technical College, Mellor taught a generation of pottery managers ; as first director of research of the British Refractories Research Association (the forerunner of the British Ceramic Research Association) Mellor initiated research at a time when industrial research was a novelty. But perhaps he is best known as the author of the "Comprehensive Treatise on Inorganic and Theoretical Chemistry".

\section{Educational Research}

THE third issue of Educational Research, the journal of the National Foundation for Educational Research in England and Wales, contains articles on the teaching of mathematics, the ability to teach, the effect of environment on intelligence, school guidance services and a comparison of attainments in different types of primary school. There is also a selected and annotated bibliography of works on the curriculum of the secondary school (Newnes Educational Publish. ing Co., Tower House, Southampton St., Strand, London, W.C.2. 5s. 6d.). In the article on the teaching of mathematics, Mr. J. B. Biggs discusses the distaste for school mathematics so commonly reported. His conclusions evaluate the relative effect of basic personality and specific likes and dislikes, particularly in the ease of the maladjusted child. Many so-called lazy children are seen to have found an initial block to their number learning because of their temperament. This is heightened by accusations of laziness and consequent unimaginative driving by some teachers. The implications of this and the other stimulating conclusions are important to the teacher who might well ask himself why there is no similar anxiety concerning English.

\section{A New Geological Documentation Service}

THE wealth of information available constitutes a serious problem for the future of the research in the Earth sciences. Before 1939, published work could be covered by giving about one thousand references a month. At present, the Service d'Information Géologique of the Bureau de Recherches Géologiques, Géophysiques et Minières indexes monthly more than 3,000 references, and it is estimated that 5,000 references should be given to ensure complete coverage of the field. The situation is complicated by the number of works now appearing in little-known languages, and by the launching of new periodicals and special publications. Faced with this problem, the Service d'Information Géologique of the Bureau de Recherches Géologiques, Géophysiques et Minières, which has taken over and expanded the work of the Centre d'Etudes et de Documentation Paléontologiques, has set itself the task of providing an extended and rapid service of basic geological information. The Service d'Information Géologique scans every week about 3,500 periodicals, more than 200 of which are published in Russian. The references are typed in the original language or, if they are not in Latin characters, are translated, usually into French; they are then classified in 1,200 sections under twelve main headings (mineralogy, petrography, stratigraphy, tectonics, geophysics, geological activities, geological phenomena, applied geology, general palæontology, biology, botany and zoology). The work is, of course, carried out under the supervision of scientists. Each reference is indexed by title and by content. The average number of indexes to each abstract card is five.

\section{Central Advisory Water Committee}

ON the expiry of the first period of appointment, the Minister of Housing and Local Government, Mr. Henry Brooke, has reviewed the composition of the Central Advisory Water Committee and made various re-appointments and new appointments. The membership of the Committee is drawn from the major interests concerned with water, for example, water supply, industry, scientists, agriculture, river boards. The Minister is chairman of the Committee, and the vice-chairman is the Parliamentary Secretary, Mr. $J$. R. Bevins. Since its reconstitution in 1955 the Committee has published reports on the demand for water in England and Wales, on information on water resources and on the law dealing with the disposal of trade effluents. 